\title{
Ergonomic and individual risk evaluation
}

\author{
Vélez V. Martha Kenny ${ }^{\mathrm{a}^{*}}$, Nolivos Verónica ${ }^{\mathrm{b}}$, Alegría Fabricio \\ ${ }^{a}$ Ft. Erg. School of Physiotherapy's Director at Universidad de las Américas. Quito Ecuador. \\ ${ }^{b}$ School of Physiotherapy's Assistant at Universidad de las Américas. Quito Ecuador. \\ Alegría Fabricio Physiotherapy's School Student at Universidad de las Américas. Quito Ecuador.
}

\begin{abstract}
The ergonomic risks constitute a vital aspect of study and prevention for the worker's health, especially for people with different capacities. Very job has and implies certain type of risk for the worker's health, depending on the conditions it is done with the use of tools or without them. Aplicated techniques: posturogram, baropodometry, Schober test, biocinemátic chain test, Fukuda test, propioceptiva plataform in personnel with special capabilities
\end{abstract}

Keywords: Ergonomic risk, posturogram, special capabilities, propioceptiva platform, preventive injuries.

1. Introduction - In general terms, every job has and implies certain type of risk for the worker's health, depending on the conditions it is done with the use of tools or without them. Ergonomics is a new scientific discipline takes into charge the relationship between the individual and his or her work.

The ergonomic risks constitute a vital aspect of study and prevention for the worker's health, especially for people with different capacities.

The main causes of the risks constitute forced postures, repetitive movements, inadequate manage of charges, between others, whose late detection may cause a serious problem not only for the different capacity worker or physically, mentally or disabled in any other way personnel as much as for the company that has hired them.

On the other hand, worldwide statistics put the musculoskeletal as the major risk in task execution, because 8 of every 10 persons present back pain that causes absence, economic loses, production delay and alteration of enterprise politics directed to sales and acquired compromises.

2. - General Objective of the Ergonomic Evaluation Concerning Individual Risk

Identify and evaluate the individual risk of workers and officials with different capacities at Universidad de las Americas.

\section{3. - Specific Objectives}

To identify the individual risk of 11 workers with special capacities at Universidad de las Americas through the use of international tools.

Recommend the preventive and corrective measures for each case.

\section{4. - Methology \\ Conceptual Aspects}

What Is The Individual Laboral Risk?

It is the possibility or probability of damages that the worker in a muscle skeleton level may suffer (director, officer, operative) in his/her laboral performance. The individual risk is product of the presence or potential appearance, or potentialization (time damage) of an activity or occupational situation capable of generate damage.

The risk situation depends on various factors, which are:

- Postural biomechanical disarrangements in which the task is done.

- Inadequate plantar support.

- $\quad$ Sustentation Base alterations.

- $\quad$ Loss of flexibility in the spinal column

- Balance alteration of the muscular chains (biocenimatic) that hold the posture or execute the task.

- Frequency with which determinate corporal segment is used.

- $\quad$ Basic daily activities

* Corresponding authors. Emails: mvelez@udla.edu.ec, vnolivos@udla.edu.ec 
- $\quad$ Sports or different types of activities the individual does.

This occupational risk conditions are treated by Clinical Posturology, a main part in ergonomics, throughout which potential injuries may detected; outcomes of the relationship between specific occupational and individual activity.

\section{Individual Risk Identification Parameters}

Individual postural standing situation.

Plantar support characteristics.

Flexibility levels of the spinal column

Cinematic Muscular chains state

Daily habits concerning activities like driving, resting, sports and others.

\section{Aplicated Techniques}

a) Postugram

b) Baropodometry

c) Schober Test or Spinal Column flexibility

d) Biocinematic Chains Test

e) Fukuda Test

f) Postural Photographic Register

g) Propioceptive COBS Platform

\section{Procedures}

In the first phase the individual risk evaluation was done using the clinical Posturological tools and correlated results with the radio graphical existent studies of the spinal column of the Medical Department of the Company.

In the second phase, eight of the worker's cinematic chains, there was a special emphasis in those cinematic muscular chains used in the most frequent work position, in order to determine the disarrangement or existent deviations.

The third one associated the two previous phases, each worker was particularly instructed for the prevention and individual correction, throughout strengthening exercises, flexibility, corrective foot pads, postural re education, etc.

\section{5. - Evaluation Individual Risk Results Evaluated Population General Characteristics}

The studied personnel were integrated by 11 workers. The distribution of age groups is registered in the following graphics.

\section{Posturogram Aplication}

Posturogram-Posturedecoding
In order to decode each of the body's parts posture, Clinic Posturology divides the evaluations in three different layouts, previous, posterior and sagital, assigning each one of the to a increasing punctuation, the lowest the risk associated to the posture.

The natural aligned positions have a punctuation of 10 , extreme postures or positions that induce to postural deviations are qualified with a 0 . Light or moderate postural deviations are qualified with a 5 . In some cases, the main posture segment and its correspondent punctuation is evaluated with a series of conditions that may contribute to increase or decrease the risk involved.

The quantified postuological method ensures that the principal body's zones are included in the analysis, because the forced positions of neck, back and legs may influence negatively in the superior extremities, becoming a serious factor that had to be considered in the risk evaluation.

\section{Baropodometry Aplication}

Individual evaluation using electronic podometer.

It allows identifying:

Static Posture

Dynamic Posture

Static Posture

Identification of the plantar arch type: normal, cave or plain

Balance with eyes open

Gravity Center

Plantar pressures: forefoot, midfoot and hind foot.

Deviations

Dynamic Posture

Walking Characteristics

Walking Biodynamic

Forward movement from Gravity Center

Plantar pressures in the support phase

\section{Spinal Column Flexibility Codification}

This test allows detecting the spinal column's flexibility index based on three factors:

Exterior leg muscle flexibility (isioquitable)

Articular hip Displacement

Spinal Column flexibility in the cervical, dorsal and lumbar flexibility.

Four risk degrees levels have been established

slow to the simulation of the race.

\section{Propioceptive COBS Plataform}


It registers the force index, defines the average.

Left and right force and the body weight measures the printed force in the Left and right independently from body weight in nanos (gravity force), where we are able to determine the force put in the hemi bodies.

\section{Personnel With Special Capabilities Group Risk} Profiles

The coordination index registers movements the higher the value the more coordination. Symmetric index defines the coherence or irregularity between measurements and time.

\section{Resultados}

\begin{tabular}{|c|c|c|c|}
\hline & & $\%$ & $\%$ \\
\hline Risk Denomination & $\begin{array}{l}\text { Risk } \\
\text { No. }\end{array}$ & $\begin{array}{c}\text { From } \\
\text { The Total } \\
\text { Of Eva- } \\
\text { luated } \\
\text { People } \\
\end{array}$ & $\begin{array}{c}\text { Of } \\
\text { The Total } \\
\text { Risk } \\
\end{array}$ \\
\hline Weak Abdominal Muscles & 8 & $73 \%$ & $10 \%$ \\
\hline Buttocks Muscles Hypotonia & 8 & $73 \%$ & $10 \%$ \\
\hline Isiquiotable Muscle Shortening & 9 & $82 \%$ & $11 \%$ \\
\hline Overweight & 0 & $0 \%$ & $0 \%$ \\
\hline Hallux Valgus & 0 & $0 \%$ & $0 \%$ \\
\hline Valgus Feet & 0 & $0 \%$ & $0 \%$ \\
\hline Inferior Members Dissymmetry & 5 & $36 \%$ & $5 \%$ \\
\hline Hip Rotation Decrease & 9 & $82 \%$ & $11 \%$ \\
\hline Scoliosis & 1 & $9 \%$ & $1 \%$ \\
\hline Varous Feet & 0 & $0 \%$ & $0 \%$ \\
\hline Cave Feet & 6 & $55 \%$ & $8 \%$ \\
\hline Rotation Shoulder Muscles Shortening & 2 & $18 \%$ & $3 \%$ \\
\hline \multirow[t]{2}{*}{ Plain Feet } & 0 & $0 \%$ & $0 \%$ \\
\hline & 4 & $36 \%$ & $5 \%$ \\
\hline Repetititve Effort Injurie & 6 & $55 \%$ & $8 \%$ \\
\hline Imbalanced Posture & 9 & $82 \%$ & $11 \%$ \\
\hline Kyphosis & 5 & $45 \%$ & $6 \%$ \\
\hline Non Ionizing Radiation & 5 & $45 \%$ & $6 \%$ \\
\hline Positive Fukuda Test & 4 & $36 \%$ & $5 \%$ \\
\hline \multicolumn{4}{|l|}{ TOTAL OF RISKS } \\
\hline TOTAL OF PERSONNEL & 11 & & \\
\hline
\end{tabular}




\begin{tabular}{|l|c|c|c|c|c|}
\hline Type & $\begin{array}{l}\text { High } \\
\text { Impact }\end{array}$ & $\begin{array}{l}\text { Or- } \\
\text { thesist }\end{array}$ & $\begin{array}{l}\text { Up- } \\
\text { grades }\end{array}$ & $\begin{array}{l}\text { Finger } \\
\text { Sepa- } \\
\text { rators }\end{array}$ & Heel Soles \\
\hline $\begin{array}{l}\mathbf{N}^{\circ} \text { of } \\
\text { rescrip- } \\
\text { ciones }\end{array}$ & 5 & 8 & 4 & 1 & 9 \\
\hline
\end{tabular}

\section{Prescribed Foot Pads}

\section{Bibliografía}

Willem Georges -Manual of Posturology -Editions FrisonRoche 1999.

Rossato Massimo- Philippe Villeneuve- Est Podologue, Président De L'association De Posturopodie In7.Internationale. Italie 2003

Gallozi Claudio. "Posture "Dpto. De Fisiología Y Biomecánica. Coni. Italia.2003

Levy Benasuly Ana-Cortés José- "Ortopodología Y Aparato Locomotor". Editorial Masson- Barcelona España2003

La Reprogrammation Posturale Globale » Sauramps Médical. By Doctor Bernard Bricot.S.B.N. 2840231107. 13008 Marseille. France.

Moreno De La Fuente J." Podología General Y Biomecánica”. Editorial Masson. Barcelona España-2003

Lisandro L. "Posturología E Oculística". Ospedale Pediatrico "G. Di Cristina" - Palermo-Unità Operativa Di Oculistica 2002

Busquet.L. "Las Cadenas Musculares". Ediciones Paidotribo-España.2001

Gagey P.M., Martinerie J., Pezard L., Benaim Ch. (1998) L'équilibre Statique Est Contrôlé Par Un System Dynamique Non-Linear. Ann. Oto-Laryngol., 115: 161-168.

Amadio, A.C. Fundaments Biomecânicos Para A Análise Do Movimento Humano. São Paulo.: Laboratório De Biomecânica - Eefeusp, 1996, 162p.

Villeneuve Frisson Roche Ed. Pied, Equilibrium Et Posture. París. 2001
Gagey P-M, Bizzo G, Bonnier L, Gentaz R, Guillaume P, Marucchi C. (1990) Hit leçons de Posturologie. Association franchise de posturologie. 2003

Palacín Montserrat "Pintos de rupture con la Fisioterapia classical". Centre Teràpies Globals. Barcelona España 2003.

Duarte Marcos. “ Model Gem Do Control Postural Humano.Ix Congress Brasileiro De Biomecánica. 2001Gramado Brasil.

Woollacott, M.H.; Shumway-Cook, A. Motor Control Theory And Practical Applications .Williams\&Wilkins. Baltimore, 1995.

Lehmkuhl, L.D.; Smith, L.K. Cinesiologia Clínica De Brunnstrom. 4a Ed. Editor Manole São Paulo., 1989

Benagniano Ezlo. "Postural A. I. Artificial Intelligence" La Diagnostica. Roma Italia. 2003.

Lelievre, J. "Patolología Del Pie" Toray M. Pág. 57.

Vélez Martha K . "Fisioterapia-Sistemas - Métodos Técnicas” Sur Editores. Quito.1997

Vélez Martha K. "Posturologia Clinica" Ediciones Universidad De Las Américas. Quito Ecuador.2011.

Viladot Perice, A. "Patología Del Antepié" Toray M. Pág. 1 - 5. Barcelona 1.981 .

Viladot Perice, A. "Clínica Y Tratamiento De Las Enfermedades De Los Pies" Edic. Científica Médica. Pág. 111. Barcelona 1.959

Pélissier J.,V. Brun, M Enjalbert. Posture Equilibration Et Médecine De Rééducation, Masson Ed. Paris.

Goldcher A-“Manual De .Podología”. Editorial MassonBarcelona- 1992

JOUVENCEL M.R. "Ergonomía basic aplicada a la Medicina del Trabuco". Ediciones Díaz de Santos. Madrid. 1994.

WEISS E.B.: " Sollecitazione Alla Giunzione LomboSacrale". La Colonna Lombare Ortopedia Clinica. Vol. 2, N. 3, Il Pensiero Scientifico Ed. Roma, 1977); (Bernard Bricot: " La Riprogrammazione Posturale Globale". Ed. Sauramps Medical 1996). 